\title{
Willa Cather and Dutch Golden Age Painting
}

Just before I began the book I had seen, in Paris, an exhibition of old and modern Dutch paintings. In many of them the scene presented was a living-room warmly furnished, or a kitchen full of food and coppers. But in most of the interiors, whether drawing-room or kitchen, there was a square window, open, through which one saw the masts of ships, or a stretch of grey sea. The feeling of the sea that one got through those square windows was remarkable, and gave me the sense of the fleets of Dutch ships that ply quietly all the waters of the globe ... 'On The Professor's House' (December 12 ${ }^{\text {th }}, 1938$ ).

When Willa Cather compared her novel, The Professor's House (1925), to a Dutch painting, in which the immediate domestic scene is counterbalanced by a wider panoramic shot through a window, she exposed a literary aesthetic in which the visual and the verbal collide. The novel, arguably Cather's most experimental, interweaves the story of Tom Outland's adventures on the Blue Mesa of New Mexico between the suffocating domestic scenes of Godfrey St. Peter's household. The shape of the novel, a sapphire set in dull silver, as the novel's epigraph suggests, is especially interesting. It presents as its most sacred core not that which is foregrounded, implicit even in the novel's title, St. Peter's home, his familial travails and his professional anxieties, but the world beyond that $\sim$ the world beyond the home, the parish, the family. Indeed, one might argue that much of Cather's work presents a tension between the strictures of regional domesticity and the dream of an exotic world beyond the parish. Her characters are often those who yearn to escape parochial settings in search of city success and freedom. Indeed, such characters mirror the trajectory of Cather's own life: her move from the Nebraska prairies, which shaped her literary reputation, to Lincoln, Pittsburgh and later New York City. Yet Cather has been categorised as a regional writer, a local-colourist, and in some instances a nostalgic anti-modernist. Indeed, as Guy Reynolds has observed, Cather was conscious of her reputation and willingly embraced it. But although the 'regionalist' tag first brought Cather national success, it has also served to restrict her literary reputation. And the misconceptions associated with Cather's supposedly nostalgic Nebraska affiliation belie the author's deep immersion in national and international cultures. ${ }^{\text {i }}$

Scholars have long explored Cather's literary influences, both American and European, her taste in the musical and the culinary arts, and her deployment of Greek and Latin epic conventions and allusions throughout even the earliest of her fiction. ${ }^{\text {ii }}$ Yet the assumption of parochialism persists. ${ }^{\text {iii }}$ One of the reasons for this, of course, is the success of Cather's earlier novels, namely O Pioneers! (1913) and My Ántonia (1918), which were deeply rooted in her Nebraska settings. Another is her fascination with the processes of memory and recovery, her lifelong interest in origin, purity and identity. ${ }^{\text {iv }}$ However, even in these early novels, Cather's world is much wider than the prairie. Certainly the prairie location and context are enormously important for the stories. Indeed, Cather's poetic descriptions of the landscapes her protagonists inhabit rank among some of her novels' most memorable scenes. However, the world Cather presents in these earlier books is distinctly modern and multicultural, teeming with immigrant voices and stories in all their discordant polyphony. The problem, therefore, is less the regionalist label, and more the nostalgic undertones and cultural homogeneity that regionalism is perceived to represent, a uniformity which actually flattens out the richness and diversity of the region and which is perceived as the antithesis of industrialisation, cosmopolitanism and modernism. 
While Cather's work has long been unpicked for its European allusions, intertexts and influences, scholars have rarely asked why the author was so intent on cramming her writing with references to the works of classical writers such as Virgil, Homer and Euripides as well as French and Russian writers such as Balzac, Flaubert and Tolstoy. Why was she so interested in bridging that Atlantic gulf? Considered in this regard, Cather's writing occupies a transitional zone between cultures, situated 'on the divide' between old and new worlds, between the regional world and the modern international terrain. ${ }^{v}$ But she does not straddle this 'divide' comfortably. There is in Cather's work a profound sense of loss and a desire to rekindle cultures that are at the brink of extinction (one thinks, for instance, of the cliff dwellers in The Professor's House (1925) or the various Southwestern Indian communities in her 1927 novel Death Comes for the Archbishop) or on the threshold of assimilation. And, as Reynolds and others have pointed out, the preservation of these distinct cultures against the wider forces of Americanization suggests a writer deeply attuned to the socio-political and ideological concerns of the day. Moreover, it suggests a writer deeply suspicious of the project of Americanization and the idea of a 'naturalised inheritance'. ${ }^{\text {vi }}$ Rather disarmingly (due to its seeming simplicity), Cather's work in its themes and in its formal composition problematizes overarching nationalist agendas.

During Cather's lifetime, one of her most sympathetic reviewers was the antiwar intellectual and sometime writer for The Dial, Randolph Bourne. In his review of My Ántonia in 1918, Bourne described Cather as belonging to the international group of modernist writers - a seemingly curious description when one considers that this is supposedly one of the books that most firmly situates Cather in the prairies. However, a closer look at Bourne's writing reveals a conception of region, indeed even of nation, as distinctly cosmopolitan. For Bourne, the term 'trans-national America' referred to 'a federation of cultures', 'a cosmopolitan federation of national colonies, of foreign cultures' with 'an intellectual internationalism ... [interested in] different cultural expressions'. He envisaged America as a nation of immigrants who could 'retain that distinctiveness of their native cultures' and hence be 'more valuable and interesting to each other for being different', a nation of 'cosmopolitan interchange ... in spite of the war and all its national exclusiveness' ${ }^{\text {vii }}$ Indeed, for Cather any kind of Americanization - and even the doctrine of the melting pot - presents precisely the cultural (and racial) homogeneity she abhors. And while certainly elegiac in tone, her novels offer not a lament for any stable American or regional identity but a repudiation of an Americanized identity which threatens to eradicate diverse cultures. ${ }^{\text {viii }}$ Therefore, Cather's commitment to 'cosmopolitan interchange' reveals an aesthetic based on transatlantic (and trans-generic) cross-pollination.

Indeed, in her 1938 letter, 'On The Professor's House', Cather writes that she deliberately engaged with French and Spanish forms to present an antithesis to the stifling conformity of St. Peter's American house. 'In my book,' she writers, 'I tried to make Professor St. Peter's house rather overcrowded and stuffy with new things; American proprieties, clothes, furs, petty ambitions, quivering jealousies - until one got rather stifled' ix Thus the world of St. Peter and his daughters is less the protected and vulnerable space identified by critics such as Walter Benn Michaels, than a space which threatens to infect, commodify and eradicate immigrant and indigenous cultures. ${ }^{\mathrm{x}}$ Far from being an exercise in inward-looking parochialism, Cather's methodology reveals a writer attuned to the wider dangers of cultural conformity and pressing the need for transcultural literary experimentation. With this in mind, I propose a closer look at Cather's second experiment in form, the integration of the 
painterly methods of the Dutch Masters, particularly the work of Johannes Vermeer, with fiction writing. ${ }^{\mathrm{xi}}$ Such transcultural influences and elements of Cather's fiction reveal a method which transcends the borders of generic classification. In fact, Cather herself writes of this overlap between the visual and the verbal artist in 'On the Art of Fiction' (1920) where she writers of her admiration for the work of Jean-François Millet. For Cather, Millet finds 'what conventions of form and what detail one can do without and yet preserve the spirit of the whole - so that all one has suppressed and cut away is there to the reader's consciousness as much as if it were in type on the page. 'xii Later, writing on Death Comes for the Archbishop, she notes her literary debt to the symbolist artist, Puvis de Chavannes. 'I had all my life wanted to do something in the style of legend, which is absolutely the reverse of dramatic treatment.' She writers. 'Since I first saw the Puvis de Chavannes frescoes in my student days, I have wished I could do something a little like that in prose; something without accent, with none of the artificial elements of composition.' ${ }^{\text {xiii }}$ In approximating the ideals and methods of painting Cather, like many of her more celebrated modernist peers, evinces a visual aesthetic in the forms of fiction, thereby melding an experimental writerly methodology with her political commitment to transcultural representation.

Critics frequently comment on the pictorial qualities of Cather's fiction. One of the most arresting images in all of her work is the image of the plough set against the orange disc of the setting sun in My Ántonia, but there are countless other exercises in portraiture and landscape, from the braided, blonde Alexandra Bergson to the fading Southern belle Sapphira Colbert, from Tom Outland's New Mexican stone city to the angular, dark contours of Quebec in Shadows on the Rock. Her work abounds with artists and sculptors, from Harvey Merrick in 'The Sculptor's Funeral' to Jules Martel of 'Flavia and Her Artists'. Indeed, Cather's second collection of short stories, Youth and the Bright Medusa (1920) is comprised entirely of stories about literary, musical and visual artists. Of this collection perhaps the most interesting story is perhaps 'Coming, Aphrodite!', Cather's most sensual and erotically charged of works. The story relates the heady, summer-long relationship between an avantgarde artist, Don Hedger, and an aspiring singer, Eden Bower. Hedger, a curmudgeonly loner, committed to art for art's sake, find himself invigorated by a new neighbour who he watches through a knothole as she practises her calisthenics in the nude. On one level, the story is about the relationship between an artist and his subject (though Eden does not sit for Hedger). On another, it is a story about power and the dynamic interplay between the voyeur and the watched, for is not until the end of the story that we learn that Eden has all the time been aware that Hedger has been surreptitiously watching her through the knothole between the apartments. She stuffs the viewing eyelet with the same writing paper that she uses to call an end to their relationship, using the receptacle of words to block his vision. But above all, 'Coming, Aphrodite!', offers a formal experiment involving the relationship between verbal and pictorial space. As with a piece of visual art, the story raises interesting ideas about the position of the viewer, the observed object which occupies space, and the relationship between the viewer and the object. The story plays with ideas of surface, depth, perspective, framing and pictorial unity, and it maintains Cather's commitment to transcultural and trans-generic experimentation.

The pictorial quality of the short story is not unique to Cather's work. Indeed, Washington Irving, one of the first practitioners of the genre in the United States, described the short story as a 'sketch', a form he described as a 'familiar and faithful exhibition of scenes from common life'. ${ }^{\text {iv }}$ The great theorist of the nineteenth-century short story, Edgar Allen Poe, pioneered the highly wrought narrative form of the short 
story. For Poe, every element of the short story had to contribute to its overall meaning and impression: 'A skilful artist has constructed a tale. ... by such means, with such care and skill, a picture is at length painted which leaves in the mind of him who contemplates it with a kindred art, a sense of the fullest satisfaction. ${ }^{\mathrm{xv}}$ Again we encounter the painterly metaphor, the notion of the short story as presenting a kind of picture. This picture is not directly presented by Poe as a kind of visual edifice, yet the recurrent reference to the pictorial qualities of the short story suggest that the genre has the capacity to make us 'see' something. Poe seems to suggest that because the short story can be read over a relatively short period of time, so it can, like a painting, be more readily grasped as an aesthetic whole. Its spatial, temporal and structural elements can be exploited for aesthetic effect in ways not possible over the longer time course of the novel.

This aesthetic effect, the psychological or emotional effect wrought on the reader is, in many ways, similar to the notion of epiphany most commonly associated with James Joyce and the moderns; as Robert Langbaum explains, 'it is the manifestation in and through the visible world of an invisible life'. ${ }^{\text {vi }}$ Epiphany collapses time into a moment of vision. Cather speaks precisely of this effect when she describes the aim of her writing as the evocation of 'the thing not named', emphasising less the importance of words but a revelatory wordlessness. ${ }^{\text {xvii }}$ Thus, it is the visual, rather than the verbal, that is emphasised in the short story. Writing on the form, Clare Hanson notes the shift from the traditional, plotted story to "plotless fiction' as "part of a wider movement from "discourse" to "image" in the art and literature' of the beginning of the twentieth century. She argues that Poe's theory of the short story is a 'symbolist aesthetic one', which invites a spatial reading, a pictorial analogy, of the short story. ${ }^{\text {xvii }}$ Similarly, Valerie Shaw argues that the short story has its own aesthetic, which reveals affinities with painting and photography. ${ }^{\text {xix }}$ An engagement with visual forms was a beguiling opportunity for many modern writers weary of the perceived limitations of words. In Virginia Woolf's appreciation of Walter Sickert, for instance, she acknowledges words as 'an impure medium', insufficient compared to what the painter can achieve 'in the silent kingdom of paint'. ${ }^{x}$

For Cather, as for Woolf, the role of the writer was to make the reader 'see' something beyond that which was literally presented. Indeed, she shares Woolf's sense of the necessary excision of words in the depiction of an overall effect and experience, as her appreciation of Millet clearly suggests. But what is particularly interesting is her admiration for the Dutch masters. For a painter such as Johannes Vermeer (or indeed Jan Steen or Pieter de Hooch), meaning is usually expressed through just one symbolic sign which becomes the dominant theme of the painting. Again, therefore, the emphasis is on distillation. As Cather notes in her famous treatise on art, 'The Novel Deméublé' (1936), 'the higher processes of art are all processes of simplification'. ${ }^{x x i}$ So, for instance, in a painting such as The Milkmaid, the symbolic object is the inconsequential foot warmer set between the delft tiles depicting images of Cupid and a man with a spear. The foot warmer, betwixt the tiles, evokes the notion of sensual pleasure (supported by the images on the adjacent tiles) as when set beneath a woman's skirts, it would have warmed the entire lower body. This, in turn, opens up a series of associated connotations, regarding the title of the painting, the shape of the mouth of the jug and the liquid which pours from it. There is an intimacy to the picture; the subject is lost in private contemplation.

The rich blue of the milkmaid's skirt, created from crushed lapis lazuli, set against the lead-tin yellow tones of the painting might remind us of Cather's turquoise 
set in dull silver in describing the narrative structure of The Professor's House. But Cather makes particular reference to the open, square windows of the paintings she saw in the exhibition. While the window in The Milkmaid does not offer views of Dutch sail ships, it does offer the opportunity for significant experimentation with light. It enables the artist to instil the figure with a fleshy, Caravaggian luminosity, rendering her almost sculptural, and inviting the viewer to contemplate the interplay of light on the back wall with the dark shadows of the kitchen corner. The window also introduces vertical and horizontal axes to the painting, with the vertical axis of the window complementing the line where the walls meet, the dropped pleat in the green tablecloth, the lines of the subject's red skirts, the comely vertical line of her bodice, and the tantalizing drip of the creamy milk as it pours from the jug. On the horizontal plane, the bottom frame of the window corresponds with the horizontal line of the table, as well as those of the basket on the wall, the foot warmer, the folds on the milkmaid's upturned sleeves, the lip of the orotund bowl into which the milk is poured, and the waist line of the ultramarine apron. All work in harmony to give a sense of that which is not named or explicitly portrayed in the painting, the sensuality, indeed the sexuality, of the half-smiling milkmaid. Furthermore, all work together in a complex atmospheric relationship to offer volume and depth to the painting, as well as situating the subject and the objects around her in pictorial space.

Writing on the subject of spatial illusion in pictorial art, William Dunning observes that "when painters write about art, they write about pictorial space - the illusion of depth on the flat surface of a painting - and its relationship to this flat surface'. xxii Noting the relationship between surface and layered pictorial depth in her comments on the paintings of the Dutch exhibition in Paris, Cather claims something similar in the narrative space of the short story. In describing the stories of Katherine Mansfield, she notes that a good short story involves delving deep into the 'secret accords and antipathies which lie hidden under our everyday behaviour'. It taps into this depth by penetrating the 'outward events': 'One goes back and runs through the pages to find the text which made one know certain things about Linda or Burnell or Beryl, and the text is not there - but something was there, all the same - is there, though no typesetter will ever set it. ${ }^{\text {xxiii }}$ Similarly, in describing the stories of her friend and mentor, Sarah Orne Jewett, stories which Cather refers to as 'sketches', she notes that 'the artist spends a lifetime in loving the things that haunt him, in having his mind "teased" by them, in trying to get these conceptions down on paper exactly as they are and not in conventional poses supposed to reveal their character; trying this method and that, as a painter tries different lightings and different attitudes with his subject to catch the one that presents it more suggestively than any other'. ${ }^{\text {xiv }}$ Clearly Cather saw something of the painter's methodology in the writers she admired, but how exactly do the 'outward events' of a short story correspond to evident elements of a painted surface? How does the writer approximate the artist in using works to portray the cohesion and density of actual objects, as an artist does with the tricks of perspective, shadowing, foreshortening, etc?

A close look at a descriptive passage from Cather's 'Coming, Aphrodite' offers some answers to these questions:

Don Hedger had lived for four years on the top floor of an old house in the south side of Washington Square, and nobody ever disturbed him. He occupied one big room with no outside exposure except on the north, where he had built in a many-paned studio that looked upon a court and upon the roofs and walls of other buildings. 
His room was very cheerless, since he never got a ray of direct sunlight; the south corners were always in shadow. In one of these corners was a clothes closet, built against the partition; in another a wide divan, serving as a seat by day and a bed by night. In the front corner, the one farther from the window, was a sink and table with two gas burners, where he sometimes cooked his food. There, too, in the perpetual dusk, was the dog's bed, and often a bone or two for his comfort. ${ }^{\mathrm{xxv}}$

Here, the text offers the reader a visual experience by describing what the narrator sees. In harmony with the theme of the story, the narrator is guided by a painterly eye which renders Cather's literary images similar to those of representational painting. In the first instance, the text is organised by a kind of metonymy; an entire view of Hedger's apartment is described on the basis of continuity, one thing leads to another. The narrator offers a kind of bird's eye view, over the roof-tops and courtyards of Hedger's surrounding building, before moving deeper into the one-room dwelling, where the corners set in permanent shadow, which hold the closet and the divan, are set against the southern corner opposite the gridded window. This contiguous tracing of a scene conforms to a kind of mapping mode, whereby the writer offers a kind of graphic precision in the presentation of realistic detail. It also introduces the notion of 'linear perspective', a geometric notion of representational painting formulated by Leon Battista Alberti (1404-1472). Painting, according to Alberti, ought to represent things as seen. Thus, pictorial space concerns the position of the viewer, the object which occupies space, and the distance between the position of the viewer the object. According to Alberti, these three elements initiate the construction of a painting as a rectangle on the surface of the painting, which can be regarded as 'an open window through which the subject to be painted is seen' ${ }^{\text {xxvi }}$ Alberti's 'open window' is, of course, rather different to the open windows observed by Cather in the Dutch paintings she admired in Paris. Yet one might claim that there is something of an overlap in the way these pictorial spaces might be considered. For Alberti, the rectangular open window represents the contours of the painting itself; it should not draw attention to itself, deny its existence as 'circumscription'. The window is a metaphor for the painting itself. In Dutch art, the function and configuration of the window is different, as the window is actually embedded within the painting - not unlike the gridded panel we see in Vermeer's The Milkmaid or the maritime scenes through a window described by Cather. In these instances, the window does not make itself invisible, but rather draws attention to its own configuration, geometric order and compositional axes. For Alberti the window that is the painting illustrates, what Dunning calls a system for 'depicting what appears to be a unified, mathematically correct illusion - of volume, depth, and the accurate placement of figures and objects in space - on a two-dimensional surface'. ${ }^{\text {xxvii }}$ And for Cather and the Dutch artists she admired, it is the actual illusory nature of spatial harmony which is foregrounded with the inclusion of a window within the window that is the artwork.

This, of course, offers something of a departure from the aesthetic effect which Cather admired in the work of Puvis de Chavannes and François Millet. It seems to instil a self-consciousness within the work, deliberately drawing attention to technique, which previously Cather had suggested ought to be imperceptible. Again, we come back to the notion of reputation and the critical evaluations of Cather as a minor realist writer rather than an avant-garde modernist, per se. ${ }^{\text {xxviii }}$ While the argument for Cather as a modernist has been made by others elsewhere, what is perhaps overlooked is the trans-disciplinary nature of her experimentalism and its 
relatively early emergence within her writing. In some ways we might see Cather as attempting to conform to Alberti's principles. From the fixed position of Hedger's top floor apartment, the narrator offers a sense of depth and relative distance: he looks down on a courtyard and out over the walls of other buildings. In a further descriptive passage this becomes more apparent still:

After lunch, Hedger strolled about the Square for the dog's health and watched the stages pull out; that was almost the very last summer of the old horse stages on Fifth Avenue. The fountain had but lately begun operations for the season and was throwing up a mist of rainbow water which now and then blew south and sprayed a bunch of Italian babies who were being held up in the outer rim by older, very little older, brothers and sisters. Plump robins were hopping about on the soil; the grass was newly cut and blindingly green. Looking up the Avenue, through the Arch, one could see the young poplars with their fresh, bright, unsmoked leaves, and the Brevoort glistening in its spring coat of paint, and shining horses and carriages - occasionally an automobile, misshapen and sullen, like an ugly threat in a stream of things that were bright and beautiful and alive (7-8).

Here the narrator describes the artist within the geometrical 'Square' looking out at the fountain; just beyond on the 'outer rim' are the wet Italian children. As she paints views further into the distance, Cather directs our line of vision (and indeed that of the artist), further up Fifth Avenue through the triumphal Washington Square Arch to the Brevoort and the sullen cars beyond. Again, the reader's eye is drawn to the horizontal and vertical planes of the description: the horizontal rim of the fountain counterbalancing and throwing further into the distance the rim of the arch; the vertical slides of the arch thrusting the viewer up Fifth Avenue, away from the Square, taking in the Brevoort on the corner of $8^{\text {th }}$ Street, before encountering a lurking, ugly symbol of modernity, the automobile, the antitheses of the horse stages encountered at the beginning of the paragraph. So, while the descriptive passage takes us along the artist's visual field to a vanishing point beyond the automobiles there is a clear sense of circumscription to that visual field, from the horses at the bottom of the Square to the cars at the top of the Avenue. But we also have a temporal circumscription, the moment between the world of the horse stage and the imminent world of the automobile. So, on the one hand, we see Cather adhering to Alberti's codification of the elements of pictorial unity, the requisites of creating a window on to a pictorial world; but on the other, we see her demonstrating the impossibility of such strictures with the imminent encroachment of modernity. Perhaps, too, her circumscription is a way of drawing attention to the limitations of her form, the short story, which must by nature end relatively soon after beginning. Cather is aware that she can capture our attention for only a short time. Thus, as early as 1920 , she seems to be experimenting with the laws of optical objectivity in her consideration of form and in her attempt to make the reader 'see' something which is not directly presented in the story.

The window is a crucial aspect of Alberti's theory of painting, presenting a unity of effect. But in Cather and in the Dutch artists she admired, this is not necessarily the case. Certainly the window in Dutch art presents another world, another reality, beyond that in the immediate foreground. Its presence draws attention, in many cases, to the technical achievement in perspective and foreshortening of the artist. The window introduces graduated increments of distance which give the 
perception of depth in a piece of art. What makes this even more complex in the composition is the gridding of the window. Returning briefly to The Milkmaid, it is interesting to note that the window before which the subject stands is not a wide open space on to another world, but a gridded window. Indeed, the grid appears throughout almost all Vermeer's work which includes the window space. It introduces yet more vertical and horizontal planes to the work, intersecting orthogonal lines, which facilitate the depth and distance required for optimum optical verisimilitude. The gridded window draws attention to the spatiality of the painting, as Rosalind Krauss has observed 'the grid states the autonomy of the realm of art.' She goes on: 'flattened, geometricized, ordered, it is antinatural, antimimetic, antireal. ... the grid is the means of crowding out the dimensions of the real and replacing them with the lateral spread of a single surface' ${ }^{x x i x}$ Krauss's treatise on grids refers specifically to twentieth-century art and symbolist painting. Nevertheless her ideas about the structure and its role in the work of visual art give rise to a tension between the grid as a device facilitating perspective and depth (as it undoubtedly was in the work of artists in the fifteenth to seventeenth centuries) and the grid as a structure which draws attention to the surface nature of the artwork. Thus we return to the idea of the work of art approximating 'things as they are' (Alberti) and to the artist's selfconscious acknowledgement of the impossibility of delivering such an objective. Krauss goes on to observe the symbolist artist's reinvention of the grid in the form of the window, a structure which is simultaneously transparent and opaque, a vehicle which admits light but which also reflects back, like a mirror. Thus, the gridded window functions on two levels; in the first instance, it illuminates and casts shadows within the painting (again, giving the perception of depth), and on another it draws attention to the viewer, deliberately bringing about a kind of self-consciousness, reminding us of the artificial nature of the artwork. Again, Krauss is interesting on this point: 'it [the grid] separates the work of art from the world, from ambient space and from other objects. The grid is an introjection of the boundaries of the world into the interior of the work; it is a mapping of the space inside the frame on to itself.' ${ }^{\mathrm{xxx}}$ What is also interesting about this consideration of the grid, and especially the gridded window in painting, is that is introduces an element of interplay between illusions of reality and assertions of artificiality. So, and perhaps at a push, what we have is a kind of power play fought out within the contours and the elements of a given artwork.

Bearing all of this in mind, it is interesting to note that the gridded window also appears in Cather's story. The many-paned studio window is mentioned in the first paragraph of 'Coming, Aphrodite!' We learn that the window is enjoyed for the views outward rather than what it admits to the room. The light which comes in from this window is limited and, for the most part, keeps the apartment in shadow. The 'perpetual dusk' absorbed through the window is, of course, inwardly reflective of the austere and joyless existence endured by Hedger and his bulldog. Stepping back from the detail of the story, to examine the structure, it is interesting to note the way in which this is carefully constructed. Broken into eight discrete chapters, 'Coming, Aphrodite!' recounts four separate stories: Don's story, Eden's story, the story of the Rain Princess, and that of Don's model, Molly Welch. All are unified within the story of the brief love affair between the artist and the singer, confined for the most part to a few summer months (although the fact that we shift forward many years later in the final section of the story demonstrates the inability of the grid to contain the subject matter). There are, of course, any number of hypothetical stories embedded within the short piece, the story of the priest who raised Hedger, the story of the nurse who lets 
to Eden, or the story of Eden's time in Paris. But for the purposes of this piece, I shall confine my analysis to those which are given greatest weight by Cather.

The four internal stories set across the eight-panel piece are separate entities, but they come together to form a seemingly unified whole, to offer the unity of effect which Cather admired in the work of Millet and de Chavannes. But by foregrounding the gridded window at the outset of the story, Cather seems to wish to draw our attention to the contours which separate the stories, the horizontal and vertical axes which compartmentalise them. Pushing this analogy a little further, to the actual details of the story, grids and windows abound, and it is telling that Cather devotes considerable attention to the spatial parameters which separate Don and Eden's apartments: the hall which is blocked by a rectangular trunk, the transom above Eden's door, the perpendicular iron ladder which stands between the apartment doors, the west-facing double doors which separate their rooms, and the wall blocked by a closet. The internal doors between the two apartments and the doors of the closet set slightly ahead of them give an impression of the depth of Hedger's apartment with the orthogonal axes they introduce to the space; but they also offer a structural analogy, a reminder of the architecture of the four-part story and the four discrete temporal planes across which the story operates - and thereby perhaps also a reminder of the impulses behind the story, the dichotomy between conscious artistic configuration and unity of effect. Hedger, we are told, is an expert draughtsman, but he rejects this architectural gridding and sketching in pursuit of great, modern art.

Another framed space in the story, again not unlike the Dutch windows noted by Cather, is the rooftop trapdoor reached by a perpendicular ladder, which Hedger uses on hot summer evenings. On the evening of Eden's arrival, Hedger retreats to this rooftop space:

He looked about over the roofs; all was blue and still, with the well-built chimneys that were never used now standing up dark and mournful. He moved softly toward the yellow quadrangle were the gas from the hall shone up through the half-lifted trapdoor. Oh, yes! It came up through the hole like a strong draught, a big beautiful voice, and it sounded rather like a professional's (11).

What is interesting here is that the contoured space, the hole in the roof, liberates Hedger from the domestic confines of his apartment. It takes him away from his thoughts of the painting which preoccupies him, the picture of the paradise fish staring out from the glass of their tank (another multi-framed scene or another 'window' of sorts), and brings him outside the 'world of his third floor studio' (149). Yet, the yellow quadrangle lures him backwards too, back to the apartment with the siren song of his new neighbour forcing him to acknowledge her artistry and talent (hitherto he has admired only her superficial, outward beauty). The orgasmic 'Oh, yes!', which alludes to the suggestive title 'Coming, Aphrodite!', is a precursor to the physical and emotional effect Eden will have on Don. The yellow quadrangle brings about a kind of connection between the pair, a communication between the inhabitants of the separate yet shared architectural space (which the paradise fish do not share with their spectators in Don's painting).

Cather's reference to the quadrilateral space created by the lines of the trapdoor and the frame of the hole in the roof conveys an interesting geometrical attention to detail. Again, it takes us back to the gridded shape of the fish tank in Don's painting from which the paradise fish stare and watch. The painting is 
described by Hedger as conveying 'the incommunicability of one stratum of animal life with another - though [he] pretended it was only an experiment in unusual lighting' (6). The painted glass of the aquarium tank calls to mind Krauss's sense of the glass window as both transparent and opaque, something which can be seen through but which also reflects back upon the observer. The fact that the fish on the other side of the glass look out upon the people on the other side gain give a sense of a two-way dynamic, the artwork revealing as much about the observer as it does about the subject. And similarly, Don's interaction with the quadrilateral space on the rooftop displays an engagement with geometrical space which goes two ways, taking him out of the domestic but also luring him back in. What the reader is left with, in this instance at least, is a kind of portrait of the artist as a means into the story but also as a means of reflecting the ideas and themes within it.

Two days after his rooftop epiphany, Hedger removes a coat from the closet against the partition:

A long ray of yellow light shot across the dark enclosure, a knothole, evidently, in the high wainscoting of the west room. He had never noticed it before and without realising what he was doing, he stooped and squinted through it.

Yonder, in a pool of sunlight, stood his new neighbour, wholly unclad, doing exercises of some sort before a long gilt mirror. ... the soft flush of exercise and the gold of afternoon sun played over her flesh together, enveloped her in a luminous mist which, as she turned and twisted, now an arm, now a shoulder, now a thigh, dissolve in pure light and instantly recover its outline with the next gesture. Hedger's fingers curved as if he were holding a crayon; mentally he was doing the whole figure in a single running line, and the charcoal seemed to explode in his hand at the point where the energy of each gesture was discharged into the whirling disc of light ... (14).

The sexual charge to the piece is evident from the shooting, phallic ray of light which penetrates the knothole and the reference to the flushed female flesh. Hedger's masturbatory pose as he grips his 'crayon' recalls the dormant, vertical chimneys aloft the rooftop. Eden is described in terms of her upright posture before the long mirror, her outline and figure forming a 'single running line' which sensuously contrasts with Hedger's hunched physique and his cupped hands. The interplay of movement and light as Eden moves cause her seemingly to disappear for a moment only to reappear again. Her movement brings to mind the muscularity and sinuousness of sculpture and draws our attention not only to her physicality but to that of Hedger who is animated to the point of explosion. Eden's resemblance to a piece of sculpture is not limited to this instance; she is later likened to 'clay' (30) in Hedger's hands and later still, after her success on the Paris stage, described as 'like a plaster cast' (44). Eden is, invariably throughout the story, the object who is watched, spied upon, seen. She is a visual object, the 'Aphrodite' of the story's title, yet the story is less about Eden than it is about Don, his artistry and the painterly aesthetic of the storyteller. While here Eden is the character who is most exposed, the one observed and watched, the passage reveals more about Don and his impulses, his parched sexual desire, his misanthropy, and his (and by implication our) position as an observer. In short, the passage illustrates the dynamic struggle for power between the subject and the painter, a metatextual version of the power play enacted over the course of their short relationship. He attempts to render her beauty and dexterity with the tools of his art 
(in vain, of course, for he only imagines he holds a crayon in his hand) but it is she who reflects back at him. Her adroit, erect grace reflects, by contrast, his crabbed, hunched existence. Later still she blocks up the viewing eyelet, thereby deliberately stymieing his vision, and ending the relationship.

All of the window-like apertures bring about a kind of epiphany in Hedger, a reflective awakening which forces him to 'see' something he had previously overlooked. Thus the voice penetrating the yellow quadrangle, flooding the vast blue space of the night sky forces him to acknowledge Eden's artistry. The sight of her body through the knothole causes him to recognise his own sexual needs and desires. And so, again, we return to the notion of the short story as facilitating some kind of 'seeing': an act of 'showing' reminiscent of David Lodge's definition of an epiphany, 'a descriptive passage in which external reality is charged with a kind of transcendental significance of the perceiver' ${ }^{\text {xxi }}$ But, as Dominic Head has persuasively argued, often what seems to be epiphany is not so, but merely a moment of 'illusory unity'. ${ }^{x x x i i}$ And this is perhaps a useful idea here, for it takes us back to the idea that within Cather's work, embedded in her entire aesthetic, is an interest in disunity, an emphasis on the artifice of literary composition. So, if one looks at Hedger's epiphanic moments, it is clear that they bring about only a momentary revelation, since his desire for Eden is sated, his mind cleared of domestic fug only for a few short summer weeks. Neither character is transformed by the end of the story and we learn that Don himself has not reached the giddy heights of modern artistic success that he desires. With the blocking of the knothole comes an end to Don's story, since we, as readers, no longer experience events through his eyes. We, like Don, no longer 'see'. Bearing in mind Head's revision of the epiphanic moment as illusory and his sense of the short story as encompassing a series of disunifying devices or tropes, we return to the grid and the gridded window in Dutch Golden Age art and in 'Coming, Aphrodite!'. The grid, according to Krauss, is a structure which draws attention to the surface nature of an art work, its lack of depth, its status as artifice. The gridded window in Cather's story performs a similar function. While undoubtedly, as demonstrated in the numerous examples cited above, Cather's orthogonal lines offer the illusion of spatial depth, there is a deliberateness to their composition. They, like Hedger's gridded window at the outset of the story, draw our attention to the literary artifice before us. They ask us, the viewer or the reader, to take note of the writer's artistry, the lines and scaffolding of the composition. Thus, the gridded window offers a viewing aperture though which we peer at the lives of others, but its very opacity makes it function as a mirror too, something which freezes the observer into a gridded, mullioned space. As a result, the viewer (whether that be the hunched figure of the artist or indeed the reader of a given story) is forced to consider his or her relationship with the subject that is beheld, becoming implicated in the artwork.

'Coming, Aphrodite!' demonstrates a shift from Cather's insistence on deft harmony towards a deeper, more disruptive art that draws attention to its own lines, divisions and rupture. It presages her best, modernist novels, and, in its engagement with the visual arts, illustrates her commitment to a literary aesthetic which is selfconsciously experimental and exceeds the canvas in its innumerable transnational influences. Perhaps Cather herself best articulates her shift in perspective, her move from an emphasis on 'unity' to art as 're-production' in an unpublished fragment, 'Light on Adobe Walls': 
The first thing an artist does when he begins a new work is to lay down the barriers and limitations; he decides upon a certain composition, a certain key, a certain relation of creatures or objects to each other. ... Nobody can paint the sun, or sunlight. He can only paint the tricks that shadows play with it, to what it does to forms. He cannot even paint those relations of light and shade - he can only paint some emotion they give him, some man-made arrangement of them that happens to give him personal delight. ... At bottom all he can give you is the thrill of his own poor little nerve - the projection in paint of a fleeting pleasure in a certain combination of form and colour, as temporary and almost as physical as a taste on the tongue. ${ }^{\text {xxiii }}$

\footnotetext{
${ }^{\text {i }}$ As Guy Reynolds, Richard H. Millington, Ian F. A. Bell and Sharon O'Brien have observed, Cather is often neglected in literary anthologies and rarely considered in most accounts of Anglo-American modernism. During her lifetime, Cather was often the subject of debate in terms of her seeming conservatism and detachment from the modern American scene. Most notable amongst her contemporary critics were Granville Hicks and Lionel Trilling who lamented the perceived nostalgia and celebration of rural values within her work. See Hicks, 'The Case Against Willa Cather', English Journal (November 1933) in James Schroeter, ed. Willa Cather and Her Critics (Ithaca: Cornell University Press, 1967), pp. 139-147; Trilling, 'Willa Cather', New Republic 90 (1937) in Willa Cather and Her Critics, pp. 148-155.

ii A wide range of scholarship uncovers Cather's European influences. Some notable examples include: Helen Dennis, ed., Willa Cather and European Cultural Influences (Lewiston: Edwin Mellen Press, 1996); Ian Bell's 'Re-writing America: Origin and Gender in The Professor's House', The Yearbook of English Studies 24 (1994): 12-43; Robert Nelson's Willa Cather and France: In Search of the Lost Language (Champaign: University of Illinois Press, 1988); Stephanie Durrans, The Influence of French Culture on Willa Cather: Intertextual References and Resonances (Lewiston: Edwin Mellen Press, 2008); Janis Stout, Willa Cather: the Writer and her World (Charlottesville: University of Virginia Press, 2000); Hermione Lee, Willa Cather: A Life Saved Up (London: Virago: 1997); and Mary Ryder, Willa Cather and the Classical Myth: The Search for a New Parnassus (Lewiston: Edwin Mellen Press, 1990).

iii Reynolds argues persuasively against the negative and parochial connotations associated with Cather's regionalism, noting her representation of lost communities not as a retreat into the past but as 'a form of regionalist commitment (and recommitment) to the "beloved community" once existed'. Furthermore, Reynolds observes that Cather weaves a progressive reform derived from Populism into her characters' lives and stories. See Reynolds, 'Willa Cather as Progressive: Politics and the Writer', The Cambridge Companion to Willa Cather (Cambridge: Cambridge University Press, 2005), pp. 19-34.

iv Bell makes a compelling argument for Cather as self-consciously and deliberately interested in the purity associated with the primitive in The Professor's House (1925), linking Tom Outland's excavations on the Mesa and St Peter's recollection of Outland's story as 'the romance of the elusive, unwritable other as a means of approaching the beginning of things'. See Bell, 'Origin and Gender in Willa Cather', p. 24. Millington also observes an interest in the primitive in Cather's writing and describes her interest in immigrant and ancient cultures as animated by the new perspectives offered by Boasian anthropology. See Millington, 'Willa Cather's American Modernism', The Cambridge Companion to Willa Cather (Cambridge: Cambridge University Press,
} 2005), pp. 51-65.

v I take the term 'on the divide', which directly refers to a section of Nebraskan prairie land between the Republican River to the South of Red Cloud and the Little Blue River which lies north of the town, from Cather's fiction where it frequently appears. David Porter makes the case that 'the divide' measures out the different personae that Cather developed for herself as both a muckraker and as a writer interested in aesthetics. Porter also makes the case that Cather's situating her fiction 'on the divide' is an oblique reference to her sexual identity which she often felt alienated her from society. See Porter, On the Divide: The Many Lives of Willa Cather (Lincoln: University of Nebraska Press, 2008).

${ }^{\mathrm{vi}}$ Guy Reynolds, 'My Antonia and the Americanization Debate', pp. 73-98.

vii Randolph Bourne, 'Trans-national America' (1916) in The Heath Anthology of American Literature, eds. Paul Lauter et al (New York: Houghton Mifflin, 2006), pp. 1637-1648.

viii See also Cather's essay on Nebraskan culture for The Nation in 1923 in which she contrasts the

'cosmopolitanism' of immigrant prairie towns with the 'pale properties, the insincere, conventional optimism of our [American] art and thought'. Willa Cather, 'Nebraska: The End of the First Cycle', The Nation (5 September 1923), pp. 236-238.

ix Willa Cather, 'On The Professor's House' (1938) in Willa Cather on Writing (Lincoln and London: Bison Books, 1988), p. 31.

${ }^{x}$ For an alternative interpretation of Cather as writer with nativist proclivities see Walter Benn Michaels's Our America: Nativism, Modernism and Pluralism (Durham and London: Duke University Press, 1995). 
${ }^{x i}$ While the 'traditional' paintings Cather describes might well refer also to those of Jan Steen or Pieter de Hooch or even Gabriel Metsu, for the purposes of this article I have selected Vermeer who is arguably the most renowned of the three. Certainly, he was a great influence upon Metsu. Furthermore, given the eroticism of the story, the implicit sensuousness of Vermeer's works seems a particularly useful reference point for my observations. I have also selected Vermeer because of his famous lapis lazuli blue and the prevalence of the colour in Cather's work. I have already mentioned the reference to the epigraph to The Professor's House, which refers to the 'turquoise set in dull silver'. The colour is significant on various levels in the novel, from the 'blue feeling' which engulfs Godfrey St. Peter to the interpolated story of the Blue Mesa. The colour is also significant in 'Coming, Aphrodite!'. It is the colour which adorns Eden when she has her first altercation with Hedger, the colour of the notepaper she uses to leave him and block the peephole between the apartments, and there are frequent references to the blue skies which frame the moon, the chimneys and the pigeons. For further information on Cather's encounters with Vermeer's work see Polly P. Duryea's dissertation thesis 'Paintings and Drawings in Willa Cather's Prose: A Catalogue Raisonné' (1993). Dissertations, Theses, and Student Research: Department of English. Paper 93. http://digitalcommons.unl.edu/englishdiss/93

xii Willa Cather, 'On the Art of Fiction' (1920) in Willa Cather on Writing (Lincoln and London: Bison Books, 1988), p. 102.

xiii Willa Cather, 'On Death Comes for the Archbishop', Willa Cather on Writing (Lincoln and London: Bison Books, 1988), p. 9.

${ }^{\text {xiv }}$ Washington Irving, 'On Style and Purpose in the Short Story', The Life and Letters of Washington Irving (1869; Charleston: BiblioBazaar, 2009), p. 46.

${ }^{\mathrm{xv}}$ Edgar Allen Poe, 'Review of Hawthorne's Twice-Told Tales' originally published in Graham's Magazine (May 1842). For the full review, see Edgar Allen Poe: Essays and Reviews (New York: The Library of America, 1984), pp. 569-577.

xvi Robert Langbaum, The Poetry of Experience (New York: Norton, 1971), p. 175.

xvii Willa Cather, 'The Novel Deméublé' (1936), in Willa Cather on Writing (Lincoln and London: Bison Books, 1988), p. 40.

xviii Clare Hanson, Short Stories and Short Fictions, 1880-1980 (Basingstoke: Palgrave, 1984), pp. 1-2.

xix Valerie Shaw, The Short Story: A Critical Instruction (Essex: Longman House, 1983), p. 13.

${ }^{\mathrm{xx}}$ Virginia Woolf, Walter Sickert: A Conversation (1934), see Project Gutenberg for an e-book: http://www.gutenberg.ca/ebooks/woolfv-waltersickert/woolfv-waltersickert-00-e.html

xxi Willa Cather, 'The Novel Deméublé' (1936), in Willa Cather on Writing (Lincoln and London: Bison Books, 1988), p. 40.

xxii William V. Dunning, Changing Images of Pictorial Space: A History of Spatial Illusion in Painting (New York: Syracuse University Press, 1991), p. ix.

xxiii Willa Cather, 'Katherine Mansfield', in Willa Cather on Writing (Lincoln and London: Bison Books, 1988), p. 110

xxiv Willa Cather, 'The Best Stories of Sarah Orne Jewett', in Willa Cather on Writing (Lincoln and London: Bison Books, 1988), p. 51

${ }^{x x v}$ Willa Cather, 'Coming, Aphrodite!' (1920) in Coming Aphrodite! and Other Stories (London: Penguin, 1999), p. 5. The title for Smart Set magazine was 'Coming, Eden Bower!'. See Bernice Slote's appendix, 'Variants in "Coming, Eden Bower!" and "Coming, Aphrodite!", for a full list of the differences between the two versions in Uncle Valentine and Other Stories (Lincoln and London: Bison Books, 1973), pp. 177-181.

xxvi Leon Battista Alberti, On Painting, trans. by Cecil Grayson (London: Penguin Classics, 1991), p. 64.

xxvii William Dunning, Changing Images of Pictorial Space, p. 35.

xxviii See especially the work of Millington, Lee and Phyllis Rose's excellent article 'Modernism: The Case of Willa Cather' in Modernism Reconsidered, ed. Robert Kiely and John Hildebidle (Cambridge: Harvard University Press, 1983), pp. 123-145.

xxix Rosalind Krauss, 'Grids', October, Vol. 9 (October 1979), p. 50.

xxx Ibid., p. 61.

xxxi David Lodge, 'Epiphany' in The Art of Fiction (London: Penguin, 1992), pp. 146-147.

xxxii Dominic Head, The Modernist Short Story: A Study in Theory and Practice (Cambridge: Cambridge University Press, 1992), pp. 49-50

xxxiii Willa Cather, 'Light on Adobe Walls' in Willa Cather on Writing (Lincoln and London: Bison Books, 1988), pp. 123-124. 